\title{
Raman spectroscopy as a tool for the identification and differentiation of neoplasias contained within lymph nodes of the head and neck
}

\author{
Linda Orr ${ }^{*}$, Catherine Kendall, Joanne Hutchings, Martin Isabelle, John Horsnell, Nicholas Stone \\ From 2nd Scientific Meeting of the Head and Neck Optical Diagnostics Society \\ San Francisco, CA, USA. 23-24 January 2010
}

The development of lymphadenopathy in the neck has many causes, in children it is often found in relation to infection and in a small but significant number it is the first presentation of lymphoma. In adults neoplastic causes predominate for example, lymphoma, squamous cell carcinoma and adenocarcinoma. The treatment modalities and prognosis for these conditions varies enormously and in the case of squamous cell carcinoma an excision biopsy can lead to significant morbidity. A major prognostic factor for the response to treatment for example in lymphoma is the extent of the disease at presentation. Pre-treatment accurate diagnosis is imperative and is a compelling argument for investment in the development of accurate, sensitive and minimally invasive diagnostic techniques, such as Raman spectroscopy.

This work seeks to investigate the ability of Raman spectroscopy to differentiate between the major neoplastic diseases of lymph nodes presenting within the neck. Raman spectroscopy at $830 \mathrm{~nm}$ has been used to extensively study lymph nodes from the head and neck and pathology related spectral signatures have been identified.

Published: 29 October 2010

doi:10.1186/1758-3284-2-S1-04

Cite this article as: Orr et al:: Raman spectroscopy as a tool for the identification and differentiation of neoplasias contained within lymph nodes of the head and neck. Head \& Neck Oncology 2010 2(Suppl 1):O4.

Gloucestershire Royal Hospital, Gloucester, UK
Submit your next manuscript to BioMed Central and take full advantage of:

- Convenient online submission

- Thorough peer review

- No space constraints or color figure charges

- Immediate publication on acceptance

- Inclusion in PubMed, CAS, Scopus and Google Scholar

- Research which is freely available for redistribution

Submit your manuscript at www.biomedcentral.com/submit
C Biomed Central 